\title{
Canopy characteristics and behavior of Nellore heifers in Brachiaria brizantha pastures under different grazing heights at a continuous stocking rate
}

\author{
Daniel Rume Casagrande ${ }^{1}$, Mariana Vieira Azenha ${ }^{1}$, André Luis da Silva Valente ${ }^{1}$, Bruno \\ Ramalho Vieira ${ }^{1}$, Matheus Henrique Moretti ${ }^{1}$, Ana Cláudia Ruggieri ${ }^{1}$, Telma Teresinha \\ Berchielli $^{1}$, Ricardo Andrade Reis ${ }^{1}$
}

${ }^{1}$ Faculdade de Ciências Agrárias e Veterinárias, Jaboticabal FCAV/UNESP.

ABSTRACT - The objective of this study was to evaluate the Brachiaria brizantha cv. Marandu canopy structure maintained at different grazing heights under a continuous stocking rate and with a dietary supplementation strategy for the animals during the rainy season. This study also intended to observe the relationships of these variables with the grazing behaviors of the heifers. The effects of three canopy heights $(15,25$ and $35 \mathrm{~cm})$ were evaluated in association with three types of supplements: one mineral and two protein/energy supplements, the first with a high rumen degradable protein and energy and the others with a low ratio. Both the protein/energy supplements were provided at $0.3 \%$ of body weight/day. The experimental design was completely randomized, with two replications and repeated measures, and took place during the period from January to April 2008. The supplementation strategies did not affect any variable related to the canopy structure. Total and green herbage masses and the ratio of green/dead material increased with canopy height. The leaf/stem ratio was higher in the lowest canopy height: $15 \mathrm{~cm}$. Changes in the canopy structure caused variations in the grazing behavior of the animals. Animals maintained in the 15-cm-tall pasture grazed for a longer time, increasing the time for each meal, but the number of meals was lower than that of the animals grazing within the 35-cm-tall pasture. The grazing time of animals receiving the energy/protein supplement was lower only in the period of the day during which it was supplied. Canopy structure is affected by sward height, and changes animal behavior. Supplementation does not affect the canopy structure of the pastures with similar heights.

Key Words: canopy height, grazing behavior, grazing time, herbage mass, number of meals

\section{Introduction}

In pasture production systems, issues related to plantanimal interactions are of great importance for the success of the activity. In this scenario, it is very important to understand the limits of the resistance and tolerance of forage plants to the animals' grazing action. Variations in the intensity and frequency of grazing affect the responses of both animals and forage crops.

The use of nutritional supplements for grazing animals may interfere with the responses of both plants and animals. Although the objective of using nutritional supplements is to increase animal performance, variations in pasture structure are often observed (Gomide et al., 2009; Bremm et al., 2008) as stocking rates increase (Roman et al., 2008), as a consequence of the substitutive or combined effects of supplementation, depending on the criteria adopted for regulating the management of animal stocking.

The management of grazing and supplementation are factors that directly influence the feeding behavior of the animals. The structure of the pasture has a strong effect on the grazing ecology (Sarmento, 2003) and influences the time of search, harvest and chewing of forage, which combine to determine the forage intake. Animals receiving energy-protein supplements also tend to reduce their forage intake due to substitution or combined effects (Moore, 1980), dedicating less time of the day to grazing activity (Pompeu et al., 2009). Under the pasture conditions in Central Brazil, Reis et al. (2010) suggested that the best time of the day to provide the supplement would be in the hottest hours, when the animals already have lower grazing activity; so, there would be no difference in grazing time or forage intake at the end of the day.

Based on the above, an experiment was performed to evaluate the pasture structures and the behavior of Nellore heifers in pastures of Brachiaria brizantha cv. Marandu managed under continuous stocking, with three sward heights, and supplementation during the rainy season.

\section{Material and Methods}

The experiment was conducted in the forage experimental sector of the Departamento de Zootecnia at 
FCAV/UNESP, Jaboticabal, São Paulo, located at $21^{\circ} 15^{\prime} 22^{\prime \prime}$ south latitude, 48 $18^{\circ} 58^{\prime \prime}$ west longitude and $595 \mathrm{~m}$ altitude. The experiment was installed in a pasture area of Brachiaria brizantha (Hochst ex A. Rich) Stapf cv Marandu (Marandu grass) established in 2001 in a red latosol (Santos et al., 2006). The experimental area consisted of 18 experimental paddocks with an area of $0.7,1.0$ or 1.3 hectare. Another 5 hectares were also divided into paddocks as a reserve area.

Maintenance fertilizer was applied four times during the experimental period. On November 14, 2007, $250 \mathrm{~kg} / \mathrm{ha}$ of the formula $\mathrm{N}: \mathrm{P}_{2} \mathrm{O}_{5}: \mathrm{K}_{2} \mathrm{O}(20: 05: 20)$ were applied. Other applications were performed on December 19, 2007, January 16, 2008, and February 28, 2008, which consisted of 100, 150 and $100 \mathrm{~kg} / \mathrm{ha}$ of urea, respectively, totaling 210, 12.5 and $50 \mathrm{~kg} / \mathrm{ha} \mathrm{N}, \mathrm{P}_{2} \mathrm{O}_{5}$ and $\mathrm{K}_{2} \mathrm{O}$, respectively, at the end of the rainy season. This division of fertilization was part of the management strategy that aided in maintenance of the treatments (canopy height). According to the Köppen classification, the climate of Jaboticabal is tropical, Awa type, with rainy summers and dry winters (Table 1 ).

On November 10, 2007, grazing for standardization was performed. For this occasion, a high grazing pressure was utilized to homogenize and reduce the mass of the forage in the experimental area from the previous dry period. After the standardization grazing, animals were removed from the experimental paddocks, allowing the free growth of grasses until they reached the criteria for each treatment, when the animals were returned to the experimental units. On December 18, 2007, all experimental animals were distributed in the paddocks; however, the evaluations were not initiated until January 3, 2008. The experimental period lasted from January 3, 2008, to April 28, 2008, totaling 116 days.

The effect of three forage heights was studied, combined with the offer of three dietary supplements, totaling nine treatments with two replications (paddocks), evaluated at every 28 days. The canopy heights were 15, 25 and $35 \mathrm{~cm}$, and the supplements were composed of one mineral salt supplement and two protein-energy supplements, one with a high ratio of rumen-degradable proteins and total digestible nutrients (RDP/TDN) and the other with a low ratio of these components. To obtain this difference in the RDP/TDN ratio, the cottonseed meal of the supplements was replaced by corn gluten meal, so that both would have the same contents of crude protein ( $26 \%$ CP) and TDN ( $82 \%$ TDN) (Table 2). The amount of protein-energy supplement provided was $0.3 \%$ of body weight (BW)/day, between 13:30 $\mathrm{h}$ and 14:30 h. Mineral salt was provided ad libitum and replenished weekly. The grazing method utilized was continuous stocking with a variable stocking rate according to the treatments. Nellore heifers were used for the study, with an initial body weight of $214 \pm 2 \mathrm{~kg}$ and age of approximately 12 months. Seven heifers were used per paddocks, totaling 126 experimental animals (14 per treatment), in addition to the 30 heifers used as equilibrium animals to maintain the predetermined height of the sward canopy. After selection, animals were identified with eartags and divided among the treatments.

The experimental phase was divided into four periods, delimited by the weighing dates of the animals $(01 / 03 / 2008$, 01/30/2008, 02/27/2008, 3/29/2008 and 4/28/2008). Combinations of canopy height and supplementation were applied in the plots according to size: plots with a smaller area $(0.7 \mathrm{ha})$ had a forage height of $15 \mathrm{~cm}$, those of $1.0 \mathrm{ha}$ had a forage height of $25 \mathrm{~cm}$, and the largest area (1.3 ha) had a forage height of $35 \mathrm{~cm}$. Thus, with the same number of test animals per paddocks (seven), large differences in the stocking rate were obtained. This strategy was used to reduce the group effect and the need to use additional animals to adjust the stocking rate.

Forage height was measured weekly by evaluating 100 random points in each paddock, with the aid of a measuring stick graduated in centimeters. Control of the stocking rate was done weekly as a function of the predetermined forage heights, i.e., when the height was greater than expected for that treatment, animals were added, and in the inverse situation, animals were removed. These procedures were recorded by summing the number of grazing days for each

Table 1 - Monthly precipitation and minimum, average and maximum temperatures during the experimental period in Jaboticabal, São Paulo

\begin{tabular}{|c|c|c|c|c|c|}
\hline Month & $\begin{array}{l}\text { Precipitation } \\
(\mathrm{mm})\end{array}$ & $\begin{array}{l}\text { Days of } \\
\text { rainfall }\end{array}$ & $\begin{array}{l}\text { Minimum } \\
\text { temperature }\left({ }^{\circ} \mathrm{C}\right)\end{array}$ & $\begin{array}{l}\text { Average } \\
\text { temperature }\left({ }^{\circ} \mathrm{C}\right)\end{array}$ & $\begin{array}{c}\text { Maximum } \\
\text { temperature }\left({ }^{\circ} \mathrm{C}\right)\end{array}$ \\
\hline December/2007 & 204.4 & 13 & 20.0 & 24.8 & 31.5 \\
\hline January/2008 & 325.0 & 22 & 20.1 & 23.5 & 29.2 \\
\hline February/2008 & 302.7 & 20 & 19.8 & 23.9 & 30.3 \\
\hline March/2008 & 108.4 & 14 & 18.8 & 23.2 & 29.6 \\
\hline April/2008 & 131.4 & 13 & 18.1 & 22.3 & 28.8 \\
\hline May/2008 & 73.1 & 4 & 14.2 & 19.1 & 26.1 \\
\hline
\end{tabular}

Data obtained from the Departamento de Ciências Exatas of the FCAV/Jaboticabal, located $800 \mathrm{~m}$ away from the experimental area. 
Table 2 - Composition of the supplements utilized during the rainy period of 2008

\begin{tabular}{|c|c|c|c|}
\hline \multirow[t]{2}{*}{ Ingredient } & \multicolumn{3}{|c|}{ Supplement } \\
\hline & Mineral salt & High RDP/TDN & Low RDP/TDN \\
\hline \multicolumn{4}{|c|}{ Composition of the supplements } \\
\hline Cottonseed meal 38 (\%) & 0 & 37 & 0 \\
\hline Corn gluten meal (\%) & 0 & 0 & 21.9 \\
\hline Megalac $^{\circledR}(\%)$ & 0 & 15 & 15 \\
\hline TDN (\% DM) & 0 & 82 & 82 \\
\hline Crude protein (\% DM) & 0 & 26 & 26 \\
\hline \multicolumn{4}{|c|}{ Guaranteed level of the supplements } \\
\hline Calcium (g/kg) & 154 & 23 & 23 \\
\hline Phosphorus (g/kg) & 90 & 6 & 6 \\
\hline Magnesium (g/kg) & 10 & 1 & 1 \\
\hline Zinc (mg/kg) & 6200 & 148 & 148 \\
\hline Iodine (mg/kg) & 124 & 3 & 3 \\
\hline Cobalt $(\mathrm{mg} / \mathrm{kg})$ & 100 & 2.4 & 2.4 \\
\hline Selenium (mg/kg) & 32 & 0.8 & 0.8 \\
\hline Monensin (mg/kg) & 0 & 80 & 80 \\
\hline
\end{tabular}

$\mathrm{RDP}=$ rumen degradable protein; TDN = total digestible nutrients

animal in a paddock. At the end of each period, the number of grazing days of all of the animals in a plot were summed and divided by the number of days in the period to obtain the stocking rate of each plot.

Forage mass was estimated using the double sampling method (Sollenberger \& Cherney, 1995), taking the forage height by using a rising plate meter. The calibration equation of the plate meter was calculated every 28 days, with the height taken at nine points per paddocks (three at average heights, three points at higher heights and three points at lower heights). At the nine points, all of the forage within the perimeter of the rising plate was harvested from the soil up. The forage was stored in identified plastic bags and taken to the laboratory for weighing and separation of green material (stem and leaves) from dead material. The fractions were dried in a convection oven at $55{ }^{\circ} \mathrm{C}$ for 72 hours and then weighed again. After obtaining the pairs of height and forage mass, a first order linear regression was performed $(\mathrm{P}<0.05)$, whose coefficient of determination ranged from 0.70 to 0.98 . On the same day of sampling, 100 readings of forage height were measured and recorded using the rising plate meter. Forage mass was estimated from the average heights of each plot through the calibration equation for the rising plate meter.

For the samples taken in the area of medium height, the morphological components were separated into leaf blade (leaf), stem and leaf sheath (stem) and dead material. After separation, the fractions were weighed and ovendried $\left(55^{\circ} \mathrm{C}, 72\right.$ hours) and then weighed again.

For the study of the grazing behavior of grazing animals, two evaluations were performed during the experimental period, one at the beginning of February and the other in late April 2008. In each evaluation, the grazing time during daytime (12 hours) was evaluated for two consecutive days for each of the seven animals in each experimental paddock. A marker was used to number the back and abdominal region of each animal for their identification. The observations were made at five-minute intervals by a previously trained team carrying binoculars and stopwatches. Three observation points located in strategic locations outside the paddocks were used, allowing the visualization of the entire experimental area without affecting animal behavior. Finally, the measurements of the grazing activity for each animal were summed in order to identify the time spent grazing during daytime. Additionally, the daytime period was divided into four intervals: early morning (from $7 \mathrm{~h}$ to 9:55 h), late morning (10 h to 12:55 h), early afternoon (from $13 \mathrm{~h}$ to $15: 55 \mathrm{~h}$ ) and late afternoon (from $16 \mathrm{~h}$ to $18: 55 \mathrm{~h}$ ). The percentage of animals grazing during each time period was evaluated to determine the peak times of grazing. The number of meals for each animal was also determined.

Meal was defined as when the same animal remained grazing for two consecutive assessments (10 minutes). 
Similarly, the end of a meal was considered to be when the animal was not grazing for two consecutive evaluations. The length of each meal was determined by dividing the time spent grazing by the number of meals.

The experimental design for the data analysis was completely randomized in a $3 \times 3$ factorial design with two replicates. A mixed model was calculated using the MIXED procedure of SAS, version 9.2 (SAS, 2008). First, the best covariance structure was selected using the BIC criterion (Schwarz's Bayesian Criterion). The main effects of forage height, supplementation strategies and periods, and the interactions between these factors, when determined to be significant by analysis of variance, were analyzed using Tukey's post-hoc test at 5\% probability; for this analysis, the LSMEANS procedure of SAS was used. For the interactions, the SLICE option of SAS was used, and the experimental periods were considered as a factor of division. The same procedure was used for the variables of grazing time and the percentage of grazing animals. The design was completely randomized with two replicates.

\section{Results and Discussion}

The lower height values observed in the managed pastures were near the expected values: 14.7 for $15 \mathrm{~cm}$ and 24.0 for $25 \mathrm{~cm}$. However, in the high pastures, the average forage height was $10 \%$ lower than expected. The biggest difference between the observed and expected heights in this treatment was obtained at the beginning and end of the experiment because of two distinct factors. At the beginning of the experiment, the difficulty in adjusting the height was because of the response of the pasture to the initial grazing and the pastures were growing freely in the adaptation phase, i.e., without the presence of animals until reaching the proposed height for each treatment. When the pastures reached the predetermined height, the animals were added. Thus, the paddocks managed to be $35 \mathrm{~cm}$ high were the last to receive the animals, which happened only days before the beginning of the experiment. When animals entered these paddocks, there was marked reduction in height. The average height of these pastures was $18.3 \%$ lower than expected because there was insufficient time for the necessary adjustment, but this reduction in height was corrected in the subsequent period.

In the final experimental period, the reduction in height was due to climatic conditions (Table 1 ), which favored the reduction of growth rates, a pattern observed in several similar studies (Molan, 2004, Flores et al., 2008). Thus, even with the reduction in the number of animals per hectare (Table 3), the pasture height was still $30.9 \mathrm{~cm}$, below the $35 \mathrm{~cm}$ proposed at the beginning of the study. The difficulty of maintaining pastures with heights greater than $30 \mathrm{~cm}$ under continuously stocked grazing has been reported in similar studies (Flores et al., 2008). Even with the difficulty to maintain the predetermined forage height during the experiment, it was possible to achieve the objective of the study by creating a gradient from low $(14.7 \mathrm{~cm})$ to medium $(24.0 \mathrm{~cm})$ to high $(31.5 \mathrm{~cm})$, which was the same for all of the supplementation strategies.

The pastures managed at $15 \mathrm{~cm}$ in height had total forage mass lower $(\mathrm{P}<0.05)$ than the pastures with 25 - and 35-cm canopy height, which were not significantly different from each other $(\mathrm{P}>0.05)$. Likewise, the dry mass of the green forage was lower in the short pasture and higher in the higher canopy height pastures (Table 4). Other authors have also reported a positive relationship between canopy height and forage mass (Fagundes et al., 1999, Flores et al., 2008). The dead forage mass did not vary with pasture height $(\mathrm{P}>0.05)$, although there was a trend $(\mathrm{P}=0.10)$ of increased forage mass in the pastures with greater height (Table 3). However, the proportion of dead material in the total forage mass decreased with increasing canopy height ( $\mathrm{P}<0.05)$. Azenha (2010), in a simultaneous study, obtained the highest rate of senescence in pastures managed at a

Table 3 - Stocking rate, forage mass and forage components in pastures of Marandu grass submited to three canopy heights during the rainy season

\begin{tabular}{|c|c|c|c|c|c|c|c|c|}
\hline \multirow[t]{2}{*}{ Variable } & \multicolumn{3}{|c|}{ Pasture height $(\mathrm{cm})$} & \multicolumn{4}{|c|}{ Experimental period } & \multirow[t]{2}{*}{$\mathrm{CV}(\%)$} \\
\hline & 15 & 25 & 35 & $1^{\text {st }}$ & $2^{\text {nd }}$ & $3^{\text {rd }}$ & $4^{\text {th }}$ & \\
\hline Stocking rate (heifers/ha) & $10.8 \mathrm{a}$ & $8.0 \mathrm{~b}$ & $6.0 \mathrm{c}$ & $8.5 a$ & 8.3ab & $8.2 \mathrm{ab}$ & $8.0 \mathrm{~b}$ & 6.1 \\
\hline Forage mass (kg/ha of DM) & $6606 b$ & $9741 \mathrm{a}$ & $10868 \mathrm{a}$ & 8944 & 8429 & 9391 & 9522 & 17.5 \\
\hline Green material (kg/ha of DM) & $3100 \mathrm{c}$ & $5054 b$ & $6250 a$ & 4973 & 4915 & 4572 & 4842 & 15.5 \\
\hline Dead material (kg/ha of DM) & 3506 & 4687 & 4618 & $4071 b$ & $3514 b$ & $4816 \mathrm{a}$ & $4680 \mathrm{a}$ & 29.1 \\
\hline$\%$ green material & $47.5 b$ & $52.8 \mathrm{ab}$ & $58.0 \mathrm{a}$ & $54.8 \mathrm{a}$ & $58.2 \mathrm{a}$ & $47.9 b$ & $50.2 b$ & 13.6 \\
\hline$\%$ dead material & $52.5 a$ & $47.2 \mathrm{ab}$ & $42.0 \mathrm{~b}$ & $45.2 b$ & $41.8 b$ & $52.1 \mathrm{a}$ & $49.8 \mathrm{a}$ & 15.2 \\
\hline Green/dead material ratio & $0.95 b$ & $1.20 \mathrm{ab}$ & $1.45 \mathrm{a}$ & $1.36 \mathrm{a}$ & $1.44 \mathrm{a}$ & $0.96 \mathrm{~b}$ & $1.04 \mathrm{~b}$ & 31.2 \\
\hline
\end{tabular}

Averages followed by the same lower-case letter in the row of each factor analyzed do not differ by Tukey's test at $5 \%$ probability. CV = coefficient of variation. $1^{\text {st }}$ period $=01 / 3 / 2008$ to $01 / 30 / 2008 ; 2^{\text {nd }}$ period $=01 / 30 / 2008$ to $02 / 27 / 2008 ; 3^{\text {rd }}$ period $=02 / 27 / 2008$ to $3 / 29 / 2008 ; 4^{\text {th }}$ period $=3 / 29 / 2008$ to $4 / 28 / 2008$. 
Table 4 - Leaf/stem ratio of Marandu grass subjected to different grazing heights in pastures with continuous stocking during the rainy season of 2008

\begin{tabular}{lcccc}
\hline $\begin{array}{l}\text { Experimental } \\
\text { period }\end{array}$ & \multicolumn{3}{c}{ Pasture height (cm) } & CV (\%) \\
\cline { 2 - 4 } & 15 & 25 & 35 & \\
\hline First & $0.71 \mathrm{aB}$ & $0.68 \mathrm{aA}$ & $0.79 \mathrm{aAB}$ & 21.5 \\
Second & $1.04 \mathrm{aA}$ & $0.75 \mathrm{bA}$ & $0.84 \mathrm{bA}$ & 14.4 \\
Third & $0.99 \mathrm{aAB}$ & $0.77 \mathrm{abA}$ & $0.61 \mathrm{bAB}$ & 26.5 \\
Fourth & $1.07 \mathrm{aA}$ & $0.78 \mathrm{bA}$ & $0.59 \mathrm{bB}$ & 14.8 \\
\hline
\end{tabular}

Averages followed by the same lower-case letter in the row and the same uppercase letter in the column do not differ by Tukey's test at $5 \%$ probability. $\mathrm{CV}=$ coefficient of variation. $1^{\text {st }}$ period $=01 / 3 / 2008$ to $01 / 30 / 2008 ; 2^{\text {nd }}$ period $=01 / 30 / 2008$ to $02 / 27 / 2008 ; 3^{\text {rd }}$ period $=02 / 27 / 2008$ to $3 / 29 / 2008$; $4^{\text {th }}$ period $=3 / 29 / 2008$ to $4 / 28 / 2008$.

greater height, a fact consistent with the trend towards a greater mass of dead material in pastures managed at a greater height. In pastures with lower height, the mass of dead material was lower; however, the proportion of dead material relative to total forage mass was greater. This difference in forage composition was due to the reduced mass of green forage in the lower-height pastures.

There were no effects of the experimental periods or of the interactions between the period and pasture height $(\mathrm{P}>0.05)$ on the total or green forage masses (Table 3 ). Nevertheless, the effect of the experimental periods on the mass of the dead material, the percentages of green and dead material and the green/dead forage mass ratio was constant. The greatest values of dead forage mass were found in the third and fourth periods, which corresponded to the late summer and early fall. Thus, the ratio of green/ dead material was higher in the first and second experimental periods and lower in the third and fourth period $(\mathrm{P}<0.05)$. In Marandu grass pastures maintained at $15 \mathrm{~cm}$, Flores et al. (2008) found no variation in the proportion of dead material during the summer and fall. However, in pastures managed at 25 and $40 \mathrm{~cm}$, they observed that the proportion of dead material was higher in the fall than in the summer. In Marandu grass pastures maintained between 10 and $40 \mathrm{~cm}$ in height throughout the year, Molan (2004) found proportions of dead material during the summer lower than in the fall, regardless of the height measured.

The proportions of stem and leaf and the leaf/stem ratio varied depending on the height of the canopy and the interaction between height and experimental period $(\mathrm{P}<0.05)$. In the first period, there was no effect of pasture height (Table 4) on the leaf/stem ratio. Subsequent periods showed higher values of this ratio in pastures maintained at a short height. As the experimental period progressed, there was an increase in the leaf/stem ratio in pastures maintained at $15 \mathrm{~cm}$. In contrast, in pastures maintained at $25 \mathrm{~cm}$ of height, the leaf/stem ratio remained constant. Finally, in the 35-cm-tall pasture, there was a decrease of this ratio with time. Azenha (2010), in a study concomitant to this one, verified that the rate of accumulation of grass stems in the 15 -cm areas was close to zero, whereas in the areas of greatest height, there was a marked increase in this variable. Other authors have also observed the intensification of stem elongation with the reduction of grazing intensity (Casagrande et al., 2010, Santos et al., 2011).

None of the variables related to pasture structure were influenced by the supply of supplements $(\mathrm{P}>0.05)$. In a review, Reis et al. (2009) reported the possibility of increasing the stocking rate with the addition of protein-energy supplements, mainly as a result of the substitution or combined effects, i.e., the animal would stop grazing on forage to consume the supplement (Moore, 1980). Gomide et al. (2009) concluded that the dietary supplementation of grazing animals increases the leaf/stem ratio, the leaf mass in post-grazing, the light interception and the leaf area index. These authors attributed these results to the increased use of forage for animals with low levels of supplementation, i.e., due to the substitution or combined effects. In contrast, Roman et al. (2008) found no effect of providing $0.9 \%$ of BW/day of energy supplement for calves on the structure of a millet pasture under continuous stocking, with a stocking rate that varied as a function of the forage mass. These authors attributed the lack of variation in the canopy structure to the adjustments in stocking. Similar effects occurred in this study, where the adjustment of the stocking rate based on pasture height allowed similar pasture structures, regardless of the supplements used.

The variables of animal behavior, such as grazing time, number of meals and time of meals are directly correlated with the abundance of forage, the pasture structure and the forage intake by the animal (Baggio et al., 2008). Euclides et al. (2000) found the grazing time to be negatively correlated (-0.79) with the voluntary intake of dry matter. Gontijo Neto et al.(2006) also found a high, negative correlation between those two variables.

In this study, the grazing time varied with the heights and grazing periods evaluated $(\mathrm{P}<0.05)$. Animals in the pastures maintained at $15 \mathrm{~cm}$ grazed $32.7 \%$ longer than those in the pastures maintained at $35 \mathrm{~cm}$. The grazing time of both of these groups did not significantly differ from the time observed for the animals in the 25 -cm pastures (Table 5). The increase in grazing time is a strategy to offset the lower instantaneous intake rate, due to the bite size reduction, and to increase the forage intake when low forage mass is available (Laca et al., 1992). Sarmento (2003) observed that animals in 10-cm-tall Marandu grass pastures showed restricted forage intake in relation to those in 
Table 5 - Ingestion behavior of Nellore heifers in pastures of Marandu grass managed at three grazing intensities with supplementation by mineral salt and a protein-energy supplement

\begin{tabular}{|c|c|c|c|c|c|c|c|c|c|c|}
\hline \multirow[t]{2}{*}{ Variable } & \multicolumn{3}{|c|}{ Pasture height $(\mathrm{cm})$} & \multicolumn{4}{|c|}{ Supplement } & \multicolumn{2}{|c|}{ Month } & \multirow[t]{2}{*}{ CV ( \%) } \\
\hline & 15 & 25 & 35 & Mineral salt & High RDP/TDN & Low & $\mathrm{RDP} / \mathrm{TDN}$ & Feb & Apr & \\
\hline Grazing time (hours) & 7.3a & 6.4ab & $5.5 b$ & $6.9 \mathrm{a}$ & $6.2 \mathrm{a}$ & & $6.1 \mathrm{a}$ & $6.1 \mathrm{~b}$ & $6.7 \mathrm{a}$ & 11.5 \\
\hline Time of meals (hours) & $1.7 \mathrm{a}$ & $1.2 \mathrm{~b}$ & $1.0 \mathrm{~b}$ & $1.6 \mathrm{a}$ & $1.2 \mathrm{~b}$ & & $1.2 \mathrm{~b}$ & $1.0 \mathrm{~b}$ & $1.6 \mathrm{a}$ & 19.1 \\
\hline
\end{tabular}

Averages followed by the same lower-case later in the row for each factor analyzed do not differ by Tukey's test at 5\% probability.

$\mathrm{RDP}=$ rumen degradable protein; $\mathrm{TDN}=$ total digestible nutrients; $\mathrm{CV}=$ coefficient of variation .

pastures measuring more than $30 \mathrm{~cm}$ in height. When breaking down the intake of forage into the components, the author concluded that the lower intake was caused by the smaller bite size in the pastures maintained at $10 \mathrm{~cm}$, even though these animals used a compensation strategy, i.e., increasing the bite rate and the grazing time.

When dividing the daytime period into four intervals, early morning, late morning, early afternoon and late afternoon, no effect was observed ( $\mathrm{P}>0.05$ ) for the interaction between height and period of the day on grazing time and the percentage of animals grazing. Thus, there was an increase in the percentage of animals grazing with reduced canopy height, regardless of the time of the day (Figure 1). The number of meals increased with increasing pasture height, but in contrast, the time of each meal in the medium and high pasture heights was lower than in the low pasture height (Table 5). This difference in meal number is consistent with the conclusion of Moraes e Carvalho (2005), that the number of meals is higher and the length of each meal is shorter in situations of abundant forage. When there is low grazing intensity and the structure is conducive to forage intake, the bites are larger (Sarmento, 2003) and intake is facilitated, which provides an increase in the consumption rate, allowing the animal to feel full and stop the meal after a shorter time.

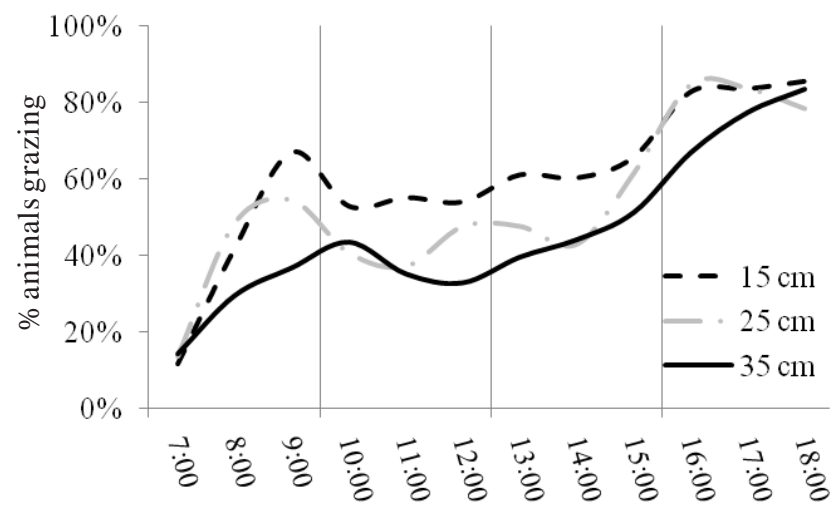

Hours of the day

Figure 1 - Percentage of Nellore heifers grazing during the hours of observation.
The grazing time increased with the advance of the experimental period through the year $(\mathrm{P}<0.05)$. This response was probably due to the reduction in the ratios between green/dead and leaf/stem material, making the forage manipulation for the formation of a bite more difficult (Table 3 and 4). Another explanation for the increased grazing time is the reduced size of a bite, which requires the animal to spend more time grazing in an attempt to maintain the same level of forage intake. One of the factors that determine the size of the bite is bite depth, which is determined by the height of the pasture that can be grazed; this height is defined as the upper portion of the forage where a higher proportion of leaves and a lower proportion of dead material and stems is encountered (Sarmento, 2003). Molan (2004) observed a reduction in the proportion of the forage available to be grazed in the fall compared with the summer, mainly in pastures up to $10 \mathrm{~cm}$ high. This led to a decreased bite volume and, consequently, a reduction in the instantaneous rate of consumption, forcing the animals to spend more time grazing in an attempt to maintain their daily forage intake.

The greatest difficulty of harvesting the forage during the month of April (fall) was also reflected in the number of meals and duration of each meal $(\mathrm{P}<0.05)$. During this period, animals ate fewer meals per day but spent more time on each meal, confirming the assertion that the animals probably had a lower instantaneous intake rate. Thus, to achieve satiety, they remained grazing for longer periods.

There was an effect of the interaction between the experimental periods within the year and the intervals of the day $(\mathrm{P}<0.05)$ on grazing time. In the early morning, there was no difference in time spent for grazing; this was the period in which the shortest grazing time was observed, 1.06 hours. During the remaining periods of the day, animals spent more time grazing in the month of April compared with February (Table 6). Peak grazing occurred in the late afternoon, during which the animals spent 2.25 and 2.61 hours grazing in the months of February and April, respectively. Between the end of the day and the early evening, the plant has a higher concentration of non-fibrous carbohydrates 
Table 6 - Distribution of grazing time of Nellore heifers in Marandu grass pasture under continuous stocking, managed in three grazing intensities during the rainy season of 2008

\begin{tabular}{|c|c|c|c|c|c|c|}
\hline \multirow[t]{2}{*}{ Intervals of the day } & \multicolumn{2}{|c|}{ Month } & \multicolumn{3}{|c|}{ Supplement } & \multirow[t]{2}{*}{ CV $(\%)$} \\
\hline & February & April & Mineral salt & High RDP/TDN & Low RDP/TDN & \\
\hline Early morning & $1.15 \mathrm{Ca}$ & $0.97 \mathrm{Ca}$ & $1.10 \mathrm{Ca}$ & $0.92 \mathrm{Ca}$ & $1.17 \mathrm{Ca}$ & 39.8 \\
\hline Late morning & $1.21 \mathrm{BCb}$ & $1.47 \mathrm{Ba}$ & $1.56 \mathrm{Ba}$ & 1.36Bab & $1.11 \mathrm{Cb}$ & 29.1 \\
\hline Early afternoon & $1.48 \mathrm{Bb}$ & $1.68 \mathrm{Ba}$ & $1.83 \mathrm{Ba}$ & $1.48 \mathrm{Bb}$ & $1.43 \mathrm{Bb}$ & 14.9 \\
\hline Late afternoon & $2.25 \mathrm{Ab}$ & $2.61 \mathrm{Aa}$ & $2.44 \mathrm{Aa}$ & $2.45 \mathrm{Aa}$ & $2.41 \mathrm{Aa}$ & 10.7 \\
\hline
\end{tabular}

Averages followed by the same lower-case letter in the row and upper-case letter in the column do not differ by Tukey's test at $5 \%$ probability.

$\mathrm{RDP}=$ rumen degradable protein; $\mathrm{TDN}=$ total digestible nutrients; $\mathrm{CV}=$ coefficient of variation. Early morning = from $7 \mathrm{~h}$ to $9: 55 \mathrm{~h}$; late morning = from $10 \mathrm{~h}$ to $12: 55 \mathrm{~h}$; early afternoon: from $13 \mathrm{~h}$ to $15: 55 \mathrm{~h}$; late afternoon = from $16 \mathrm{~h}$ to $18: 55 \mathrm{~h}$.

compared with other times, thus the bites taken at this time provide more nutrients than during other times of the day (Champion et al., 1994). According to Carvalho (1997), the animals intensify their nutrient intake according to the levels of non-fibrous carbohydrates and dry matter in the plant during the period before sundown, which, combined with thermal comfort, explains the grazing peak at the end of the day.

The type of dietary supplementation had no interaction ( $>>0.05$ ) with the time of day of animal grazing (Table 5). Pasture structure has a great influence on grazing time (Sarmento, 2003). Thus, because the use of protein-energy supplements did not cause a variation in the structure of the pasture, it was expected that there was no effect on the grazing time of animals. The time spent per meal for the animals receiving the protein-energy supplement was lower $(\mathrm{P}<0.05)$ compared with those receiving the mineral salt supplement, although the number of meals was not altered ( $\mathrm{P}>0.05$ ) by supplementation.

The animals that consumed the energy-protein supplement, regardless of composition of the supplement, spent less $(\mathrm{P}<0.05)$ time grazing during the late morning and early afternoon compared with those receiving mineral salt. However, this difference in behavior was not observed in the early morning and late afternoon hours, when there was no difference in grazing time attributable to the type of supplement (Table 6). As reported, the energy-protein supplement was provided daily at $14 \mathrm{~h}$, which explains the behavior of the animals given the protein-energy supplement; they discontinued grazing during these periods in anticipation of receiving the supplement and were slow to reduce grazing activity.

In the late morning and early afternoon, there was a reduction in the percentage of animals grazing that received the energy-protein supplement compared with those receiving the mineral salt, due to the expectation of those awaiting the supply of the supplement. Soon after the provision of the energy-protein supplement, animals went to the troughs to consume the supplement, leading to a sharp drop in the percentage of grazing animals compared with those receiving the mineral salt supplement. After consumption of the energy-protein supplement, which lasted approximately 30 minutes, animals returned to their grazing activity with great intensity and remained there until the end of the experiment (Figure 2).

According to Bremm et al. (2005), when working with heifers, grazing time is reduced when the animals receive energy-protein supplementation. According to these authors, the reduction in grazing time is the result of more time spent at the trough, which increases with the amount of supplement provided. Bremm et al. (2008), working with sheep, also concluded that animals provided with an energyprotein supplement spent less time grazing and more time at the trough, despite not showing differences in the size and rate of bites.

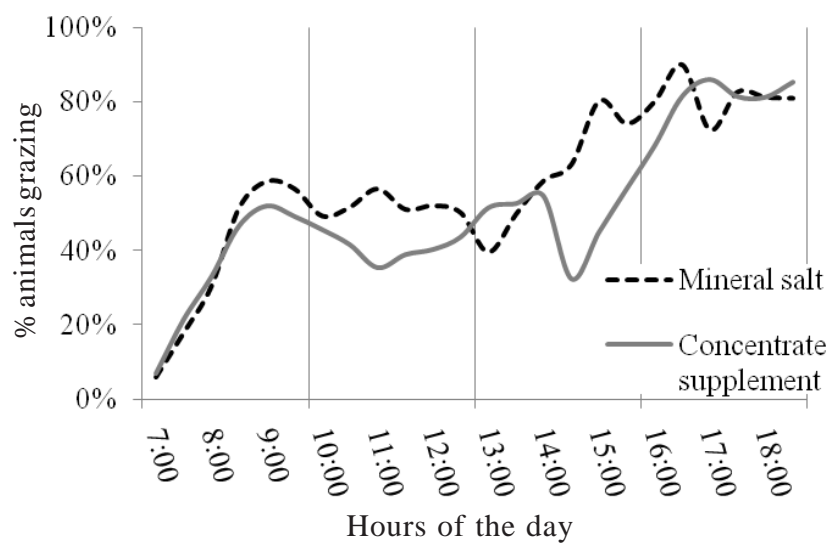

Figure 2 - Percentage of the Nellore heifers grazing during the day, varying for type of supplementation, in Marandu grass pastures managed under three grazing intensities with continuous stocking during the rainy season of 2008. 


\section{Conclusions}

There is positive relationship between pasture height and forage mass. Managing canopy height is a strategy to manipulate the structure of the pasture. Grazing activity is related to pasture height. Pastures maintained at the same height do not suffer changes in structure when using different types of dietary supplements.

\section{References}

AZENHA, M.V. Morfogênese e dinâmica do perfilhamento do capim-marandu submetido à alturas de pastejo em lotação contínua com e sem suplementação. 2010. 93f. Dissertação (Mestrado em Zootecnia) - Faculdade de Ciências Agrárias e Veterinária, Jaboticabal.

BAGGIO, C.; CARVALHO, P.C.F.; SILVA, J.L.S. et al. Padrão de uso do tempo por novilhos em pastagem consorciada de azevém anual e aveia-preta. Revista Brasileira de Zootecnia, v.37, n.11, p.1912-1918, 2008.

BREMM, C.; ROCHA, M.G.; RESTLE, J. et al. Efeito de níveis de suplementação sobre o comportamento ingestivo de bezerras em pastagem de aveia (Avena strigosa Schreb.) e azevém (Lolium multiflorum Lam.). Revista Brasileira de Zootecnia, v.34, n.2, p.387-397, 2005.

BREMM, C.; SILVA, J.H.S.; ROCHA, M.G. et al. Comportamento ingestivos de ovelhas e cordeiras em pastagem de azevém anual sob níveis crescentes de suplementação. Revista Brasileira de Zootecnia, v.37, n.12, p.2097-2106, 2008.

CARVALHO, P.C.F. A estrutura da pastagem e o comportamento ingestivo de ruminantes em pastejo. In: SIMPÓSIO SOBRE AVALIAÇÃO DE PASTAGENS COM ANIMAIS, 2., 1997, Maringá. Anais... Maringá: Universidade Estadual de Maringá, 1997. p.25-52.

CARVALHO, P.C.F.; MORAES, A. Comportamento ingestivo de ruminantes: bases para o manejo sustentável do pasto. In: MANEJO SUSTENTÁVEL EM PASTAGEM, 1., 2005, Maringá. Anais... Maringá, 2005. (CD-ROM).

CASAGRANDE, D.R.; RUGGIERI, A.C.; JANUSCKIEWICZ, E.R. et al. Características morfogênicas e estruturais do capimmarandu manejado sob pastejo intermitente com diferentes ofertas de forragem. Revista Brasileira de Zootecnia, v.39, n.10, p.2108-2115, 2010.

CHAMPION, R.A.; RUTTER, S.M.; PENNING, P.D. et al. Temporal variation in grazing behavior of sheep and the reliability of sampling periods. Applied Animal Behaviour Science, v.42, n.2, p.99-108, 1994.

EUCLIDES, V.P.B.; CARDOSO, E.G.; MACEDO, M.C.M. et al. Consumo voluntário de Brchiaria decumbens cv. Basilisk e Brachiaria brizantha cv. Marandu sob pastejo. Revista Brasileira de Zootecnia, v.29, n.6, p.2200-2208, 2000.

FAGUNDES, J.L.; SILVA, S.C.; PEDREIRA, C.G.S. et al. Intensidades de pastejo e a composição morfológica de pastos de Cynodon spp. Scientia Agricola, v.56, n.4, p.1141-1150, 1999.
FLORES, R.S.; EUCLIDES, V.P.B.; ABRÃO, M.P.C. et al. Desempenho animal, produção de forragem e características estruturais dos capins marandu e xaraés submetidos a intensidade de pastejo. Revista Brasileira de Zootecnia, v.37, n.8, p.1355-1365, 2008.

GOMIDE, C.A.M.; REIS; R.A.; SIMILI, F.F. et al. Atributos estruturais e produtivos de capim-marandu em resposta à suplementação alimentar de bovinos e a ciclos de pastejo. Pesquisa Agropecuária Brasileira, v.44, n.5, p.526-533, 2009.

GONTIJO NETO, M.M.; EUCLIDES, V.P.B.; NASCIMENTO JUNIOR, D. et al. Consumo e tempo diário de pastejo por novilhos Nelore em pastagem de capim-tanzânia sob diferentes ofertas de forragem. Revista Brasileira de Zootecnia, v.35, n.1, p.60-66, 2006

LACA, E.A.; UNGAR, E.D.; SELIGMAN, N. et al. Effects of sward height and bulk density on bite dimensions of cattle grazing homogeneous sward. Grass and Forage Science, v.47, n.1, p.91-102, 1992.

MOLAN, L.K. Estrutura do dossel, interceptação luminosa e acúmulo de forragem em pastos de capim-Marandu submetidos a alturas de pastejo por meio de lotação contínua. 2004. 180f. Dissertação (Mestrado em Agronomia) - Escola Superior de Agricultura "Luiz de Queiroz”, Piracicaba.

MOORE, J.E. Forage crops. In: HOVELAND, C.S. (Ed.). Crop quality, storage, and utilization. Madison, Wisconsin: Crop Science Society of America, 1980. p.61-91.

POMPEU, R.C.F.F.; ROGÉRIO, M.C.P.; CÂNDIDO, M.J.D. et al. Comportamento de ovinos em capim-tanzânia sob lotação rotacionada com quatro níveis de suplementação concentrada. Revista Brasileira de Zootecnia, v.38, n.2, p.374-383, 2009.

REIS, R.A.; RUGGIERI, A.C.; CASAGRANDE, D.R. et al. Suplementação da dieta de bovinos de corte como estratégia do manejo das pastagens. Revista Brasileira de Zootecnia, v.38, suplemento especial, p.147-159, 2009.

REIS, R.A.; SIQUEIRA, G.R.; CASAGRANDE, D.R. Suplementação alimentar de bovinos em pastagem. In: PIRES, A.V. (Ed.) Bovinocultura de corte. Piracicaba, 2010. p.219-253.

ROMAN, J.; ROCHA, M.G.; GENRO, T.C.M. et al. Características produtivas e estruturais e sua relação com ganho de peso de bezerras sob suplementação alimentar. Revista Brasileira de Zootecnia, v.37, n.2, p.205-211, 2008

SANTOS, H.G.; JACOMINE, P.K.T.; ANJOS, L.H.C. Sistema brasileiro de classificação de solos. 2.ed. Rio de Janeiro: Embrapa Solos, 2006. 306p.

SANTOS, M.E.R.; FONSECA, D.M. BRAZ, T.G.S. et al., Caracteríticas morfogênicas e estruturais de perfilhos de capimbraquiária em locais de pasto com alturas variáveis. Revista Brasileira de Zootecnia, v.40, n.3, p.535-542, 2011.

SARMENTO, D.O.L. Comportamento ingestivo de bovinos em pastos de capim-marandu submetidos a regime de lotação continua. 2003. 76f. Dissertação (Mestrado em Agronomia) - Escola Superior de Agricultura Luiz de Queiroz/ USP, Piracicaba.

SOLLENBERGER, L.E.; CHERNEY, D.J.R. Evaluating Forage Production and Quality. The science of grassland agriculture. Iowa State University Press, 1995. p.97-110.

STATISTICAL ANALYSES SYSTEM - SAS. SAS/STAT 9.2 User's guide. Cary: SAS Institute, 2008. 1680p. 